\title{
Analysis Of L1 And L2 Use In Spanish College Courses Using The COLT Observation Scheme
}

\author{
Graziela Rondon-Pari, Ph.D., SUNY The College at Brockport, USA
}

\begin{abstract}
This research tries to find answers to the following questions: How much English and how much Spanish is spoken in class? For what functions is each language used? Data were obtained from the tape recording of Spanish conversation classes. Other data sources included non-participant observations and an interview with each of the instructors. The COLT (Communicative Orientation of Language Teaching), part B, was used to define categories of analysis of language. Results seem to indicate that there was a large amount of focus on grammar, and use of restricted and minimal linguistic forms.
\end{abstract}

Keywords: COLT Observation Scheme; Spanish Classroom Discourse; Input; Output; Spanish Methodology

\section{INTRODUCTION}

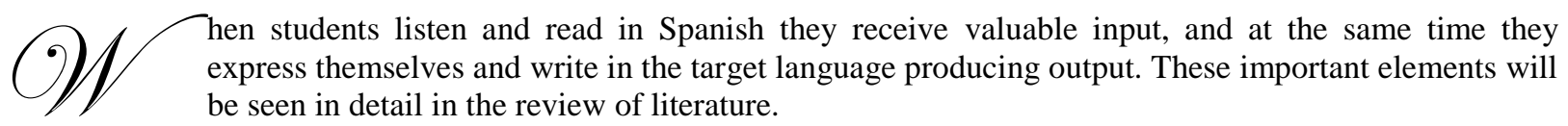

Input

The input in the classroom comes especially from the teacher, but there could also be input generated by the students, either through group work or interaction in the target language. This study takes into consideration input coming from both, students and instructors.

Target language use, especially at higher levels is necessary (Chaudron, 1988; Day, 1985; Krashen, 1985). Day (1985) explained: "It is widely assumed that the use of the target language is one of the crucial variables in the successful acquisition of the target language - the more often students use or practice the second or foreign language, the more likely they are to learn it" (p. 257).

On the other hand, input should be meaningful and comprehensible (Krashen, 1985). Regarding the first factor, Selinker (1972) explains that psychologically relevant data in second language learning as well as relevant behavioral events lead to meaningful performance and therefore are relevant to second language learning. From there the importance of putting into practice the concepts and vocabulary learned in class.

Regarding the second factor, comprehensible input, Krashen proposed the input hypothesis, which is summarized by Gass and Madden (1985): "in order for acquisition to take place learners need to have comprehensible input. They further claim that this input must be at a stage slightly beyond the competence of the learner (i+1)" (p. 5). We see that without comprehensible input there is no acquisition; input drives the acquisition process. At the same time, given that one step over the students' level may not correspond to native speakers discourse the type of speech used by the teacher, as well as the other sources of input will rather have to be simplified by using "foreigner talk". 
Gass and Madden (1985) explain, "Some of the salient characteristics of FT [foreigner talk] are slower rate of speech, louder speech, longer pauses, common vocabulary, few idioms, greater use of gestures, more repetition, more summaries preceding utterances, shorter utterances, and more deliberate articulation" (p. 4). With the use of foreigner talk students may understand simple speech without the teacher having to dictate the class in English and therefore use the target language.

\section{Output}

Just as there is comprehensible input there needs to be comprehensible output. Swain's (1995) output hypothesis supports the idea that comprehensible input is not enough to promote language learning, but that comprehensible output is also necessary. In other words, receiving comprehensible input and producing comprehensible output are essential to second language learning.

Comprehensible output implies "the delivery of a message that is not only conveyed, but that is conveyed precisely, coherently, and appropriately" (Swain 1985, p. 249). A necessary way of improving comprehensible output is by speaking. Therefore, there is a necessity of communicative oriented foreign and second language classrooms that encourage and push students to produce the L2 (Day, 1990; De la Fuente, 2002; Allen, Fröhlich and Spada, 1983).

The importance of output is underlined by Pica (1996), "comprehension of unfamiliar L2 input and production of modified interlanguage output are what are needed if learners are to move beyond their current level of development (p. 2). As we see, noticing, awareness of one's gaps in communication and the metalinguistic function of reflection are important factors and reasons to push students into producing the target language.

\section{Need for the study}

The training of new teachers in contemporary teaching procedures during their student teaching and first years of service is very important in instilling in them appropriate approaches to teaching language that are known to provide better results than older ones. This issue of being acquainted with the latest foreign language methodology is recognized by ACTFL (American Council on the Teaching of Foreign Languages) in their requirements for foreign language teaching programs to become nationally accredited (ACTFL 2002). As Spanish is the most popular foreign language taught in the United States (Stavans, 2005), research on Spanish classroom discourse that may lead to better pre-service teacher training is a necessity.

\section{METHODOLOGY}

\section{Participants}

Participants were three college instructors teaching each an intermediate level Spanish conversation class.

\section{Participant \#1}

The first instructor was born in Central America and came to the United States in the early nineties to pursue higher education. She received a bachelor's degree and a master's degree in Spanish in a large state university in the West Coast and obtained her Ph.D. in Spanish literature in Western New York. At the time of this study it was her fourth semester as a full time assistant professor at a private college in the northeast.

\section{Participant \#2}

Instructor \#2 was originally from the New England area. She started studying Spanish in high school, continued studying the language in her undergraduate and graduate studies at an Ivy League university. She had over twenty years experience teaching the language at all levels, graduate and undergraduate. 


\section{Participant 3}

The third instructor was originally from South America and came to the United States after finishing his junior year in college. He transferred as an undergraduate student to a large state university in the Northeast, graduated from this university with a bachelor's degree in education and continued graduate studies in Latin American literature in the Midwest. At the time of the study he was teaching two classes at a state university in the Northeast.

\section{Spanish Conversation Class}

There were three sections of this two hundred level conversation course. Two of the sections took place at a small private college, while the other section of the same level took place at a large state university. Students who enrolled in this course were supposed to either have taken two semesters of the language at the two hundred level or be placed in this conversation course by taking the college's foreign language placement test. There were male and female students whose native language was English.

\section{DATA COLLECTION}

Data was collected through five fifty-minute class observations of each of the three sections, for a total of 15 sessions. Data sources included an interview with each of the instructors. The techniques for collecting the data were non-participant class observations, the use of field notes, the recording of classes and an interview with each of the instructors. Class observations were performed by keeping a written record of the most relevant aspects that took place in the classroom.

\section{COLT Categories}

The COLT (Communicative Orientation of Language Teaching) was used to define categories of analysis of language in this study, with the addition of a subcategory, "oral report", which is explained under the information gap category. The COLT is an "observation scheme that provides a macroscopic analysis of L2 classrooms at the level of activity type and the verbal interaction within them" (Spada \& Lyster 1997, p. 788). The COLT was first used "in the early 1980's to describe differences in the communicative orientation of language teaching and to determine whether and how this contributes to differences in L2 learning outcomes" (Spada \& Lyster 1997, p. 788).

This observation scheme has several categories arranged in two parts. The creators of the COLT explain that "Part A describes events at the level of activity, and part B analyses the communicative features of verbal exchanges between teachers and students as they occur within each activity" (Allen, et al. 1983, p. 234). Given that the observation of the fifteen Spanish classes in this research study focus on language analysis, it was decided to adopt part B of the COLT scheme. COLT has "... been used primarily in classroom research that is intended to look at how differences in teaching practices are related to differences in second language learning" (Lightbown \& Spada 2006, p. 115). The categories contained in part B of the COLT observation are: use of target language, information gap, sustained speech, reaction to code or message, incorporation of preceding utterances, discourse initiation and relative restriction of linguistic form. Each of these categories is explained separately.

\section{A. Use of target language.}

In this category the observation focuses on differentiating between the use of the English and Spanish languages in the classroom in both, students and the instructor.

In order to be able to analyze classroom speech, the classes were tape recorded. To find out the approximate amount of L1 (English) and L2 (Spanish) that took place in the classes observed a device that sounded every five seconds was used. In that way when the sound took place, every five seconds, the researcher made a check mark in the observation form, indicating if the utterance taking place at the sound was in English or Spanish. 


\section{B. Information gap.}

Allen, et al. (1983), indicate: "Communication must have a purpose-the giving, receiving, or requesting of information" (Allen, et al. 1983 p. 240). There are two parts within the information gap category: requesting information and giving information. At the same time each of these two parts divides into two subdivisions: pseudo requests and genuine requests, for the requesting information part, and predictable as well as unpredictable, for the giving information one. We will see each sub category and subdivision separately.

Giving information: This subcategory takes place when either a student or the instructor speaks without asking a question, but stating information. At the same time, this information can be predictable, unpredictable or, a third subdivision created for this study by the author of this research paper: oral report.

1. Predictable: When the information is relatively predictable "the message is easily anticipated in that there is a very limited range of information that can be given. In that case of responses, only one answer is possible semantically, although there may be different correct grammatical realizations (Allen, et al. 1983 p. 241). In the case of our study "predictable information" usually refers to grammar exercises contained in the book, for example filling in the blanks, which is information known in advance by the teacher.

2. Unpredictable information: this type of information, on the other hand, occurs when "The message is not easily anticipated in that there is a wide range of information that can be given" (Allen, et al. 1983 p. 241). Unpredictable information is characteristic of normal speech and communication (Allen, et al. 1983), when, for example, students comment on what happened to the them during the weekend or what their plans are for the next weekend.

3. Oral Reports: The third form of giving information, oral reports, was created for this study in order to be able to discriminate between the speech actually given by the students on their own and the mandatory oral reports that students were requested to do. The oral reports usually took the form of oral presentation regarding a famous Hispanic or a topic related to the Spanish speaking world. Due to the fact that these oral reports were supposed to take place in Spanish, by separating them from the previous subdivision, unpredictable information, it was possible to know the amount of Spanish that took place from the part of the students without considering these presentations. These reports took place only at the private college in which the first two instructors taught.

Requesting information: Refers to the fact whether the teacher knows the answers to the requests in advance or not. In the case the teacher does not know the answer, then it is a "genuine request". If, on the other hand, the teacher does know the answer, as in the case of the question: "¿Qué día es hoy?" [What day is it today?], in which the teacher already knows the answer, it is a "pseudo request".

\section{C. $\quad$ Sustained speech.}

This category "is intended to measure the extent to which speakers engage in extended discourse, or restrict their utterances to a minimal length of one sentence, clause or word" (Allen, et al. 1983, p. 241). This category is subdivided into three parts: ultra minimal, minimal and sustained speech.

Ultra minimal is coded for students only and refers to utterances that consist of one word, such as yes/no answers (Allen, et al. 1983).

Minimal are utterances that consist of one clause or sentence, in the case of students, while one-word utterances are coded as minimal for teachers.

Sustained speech consists of utterances that are longer than one sentence or that consists of two or more main clauses (Allen, et al. 1983). 
D. Reaction to code or message.

This category refers to the subject matter being communicated, "whether the purpose of an exchange is to focus on the language code (that is, grammatical correctness) or on the message, or meaning, being conveyed" (Allen, et al. 1983, p. 241).

\section{E. Incorporation of preceding utterances.}

This category refers to the reply made by the second party, whether she/he comments, elaborates, reformulates, etc. the message heard. There are six subdivisions of this category, as explained by Allen, et al. (1983).

1. No incorporation: No feedback or reaction is given.

2. Repetition: Full or partial repetition of previous utterance(s).

3. Paraphrase: Completion and/or reformulation of previous utterance(s).

4. Comment: Positive or negative comment (not correction) on previous utterance(s).

5. Expansion: Extension of the content of preceding utterance(s) through the addition of related information.

6. Elaboration: Requests for further information related to the subject matter of the preceding utterance.

(Allen, et al. 1983, p. 242).

\section{F. $\quad$ Discourse initiation.}

This is coded only for students and refers to the spontaneous initiation of talk on the part of the students, as opposed to responding to the teacher or classmates.

\section{G. Relative restriction of linguistic form.}

This category is also coded only for students and is concerned with the linguistic form used by the student, whether there was only one linguistic form for the student to be used or if it was up to the student to choose the linguistic form.

There are three subdivisions, as explained by Allen, et al. (1983):

1. Restricted use: The production or manipulation of one specific form is expected, as in a transformation or substitution drill.

2. Limited restriction: There is a choice of more than one linguistic form but the range is very narrow, e. g. responses to Yes/No questions, statements about the date, time of day, etc.

3. Unrestricted use: There is no expectation of any particular linguistic form, as in free conversation, oral reports, or personal diary writing. (Allen, et al. 1983, p. 243)

\section{RESULTS}

\section{Amount of Spanish and English}

The quantification of the amount of each language was estimated by using the 5 second sound device, adding the times that each language was used every 5 seconds and determining percentages for the use of each language.

It was found that Spanish was used more often than English in every class observed, except in one class.

English was used an average of $34 \%$, while Spanish was spoken $55.6 \%$ of the time. Table 1summarizes the amount of time each language was used. 
Table 1: Percentages of the use of $\mathrm{L1}$ and $\mathrm{L} 2$ in all three Participants

\begin{tabular}{|l|c|c|c|}
\hline \multicolumn{1}{|c|}{ Percentages } & English & Spanish & Silence \\
\hline Participant \#1 & $34.0 \%$ & $55.6 \%$ & $10.4 \%$ \\
\hline Participant \#2 & $18.1 \%$ & $54.8 \%$ & $27.1 \%$ \\
\hline Participant \#3 & $6.6 \%$ & $91.0 \%$ & $2.4 \%$ \\
\hline Average (Mean) & $\mathbf{1 9 . 6 \%}$ & $\mathbf{6 7 . 1 \%}$ & $\mathbf{1 3 . 3 \%}$ \\
\hline
\end{tabular}

In Table 1 we see that $19.6 \%$ of the time English was used as the means of instruction. If we take into account that $13.3 \%$ was silence we find that Spanish was spoken approximately two thirds of the time $(67.1 \%)$. We can also observe that the three participants' use of language varied. While all three instructors spoke more Spanish than English, Participant \#1 spoke English slightly over one third of the time (34\%) and Spanish slightly over half the time. Given that this was a conversation class, precious time was used in speaking English. The case of Participant \#2 was different, given that in her classes English was spoken $18.1 \%$ of the time. At the same time, Participant's \#3 classes were conducted with a high rate of target language use, an ideal situation at this two hundred level conversation course.

While the quantification of each language use is easily observable in table 1 , the quality of the speech will be analyzed in detail in the next section.

\section{Results of categorization of discourse}

Information gap: For Participant \#2, in the giving information subdivision, a large number of utterances indicate the use of predictable information, especially because of the use of fill in the blank exercises from the text and, in general, from answers to grammar exercises contained in the text and the workbook. At the same time, from the requesting information subdivision, there is a more or less half amount of genuine requests and pseudo requests. The genuine requests belong especially to the categories of questions regarding the weather, the students' health condition, comments regarding other classes and in general conversation questions from the part of the instructor. This finding is especially important because a high degree of genuine, unpredicted, request of information is characteristic of natural language use (Canale, 1983). Therefore, this type of question is appropriate for developing conversation skills, which are especially important at this level of language learning. Students' answers were mainly minimal and ultraminimal.

In the case of Participant \#1, for the giving information subdivision, there is a clear majority of unpredicted sentences, especially aimed as comments and expansion to the students' oral presentations, comments regarding the students' attire and comments in relation to her own student life. An extract from one of her classes illustrates this issue:

T: $\quad$ Ok. Y qué le pasó a la niña de ella. Tenía una hija, ¿verdad?

[Ok. And what happened to her daughter. She had a daughter, true?].

S: $\quad$ Sí, se murió.

[Yes, she died].

T: $\quad$ Ah. Murió la hija, muy bien. Y de la nota cultural que leíste, ¿qué es lo más importante?

[Oh. The daughter died, very well. And from the cultural note you read, what is the most important (thing)?]

S: $\quad$ Que aunque la educación es gratuita, ah, los chicos no asiste a la escuela.

[That even though education is free, uh, the kids does (used verb in singular form) not attend school].

T: Que hay personas que no pueden asistir. Bien señor. ¿Por qué crees?

[That there are people that cannot attend. Good, sir. Why do you think?]

The constant change of topics and constant questioning with both predictable and unpredictable questions allowed students to communicate meaningfully and required constant attention from the part of the students. 
The giving information subdivision had also a majority of unpredictable statements by the students, but in this case related to the oral presentations, which took most of the class time for the first and second classes recorded. Regarding the request for information, as in the case of Participant \#2, there was a tendency to use genuine, unexpected requests on the part of the instructor to find out information regarding their preferences, their opinion on shopping matters, and also regarding the topics covered the previous classes. There was also close to half amount of pseudo requests, regarding grammar exercises from the workbook and text, as well as a revision and frequent mention of the quiz that took place on the third class.

For Participant \#3, giving and receiving information was unpredictable, since there was seldom reference of the text, therefore no fill in exercises were given and the giving and receiving of information was more spontaneous than in the other two sections observed.

There was an extensive variety of vocabulary and forms during the initiation of class, followed by grammar instruction based on examples formulated by the students, as we see in the initiation of Participant's \#3 second class:

\author{
S: $\quad$ Mis amigos y yo sal... salimos a Canada \\ [My friends and I went to Canada]. \\ T: Ah! Fueron a Canadá. ¿A qué parte de Canadá? \\ [Ah! Went to Canada. Which part of Canada?] \\ S: $\quad$ A Clifton Hill. \\ [To Clifton Hill]. \\ T: $\quad$ A Clifton Hill. \\ S: $\quad$ Niagara Falls. \\ T: $\quad$ Ah, bueno, y qué hay en Niagara Falls, Clifton Hill? [Silence] ¿Qué hay allí? ¿Qué queda allí? ¿El casino? \\ [Ah, well, and what is there in Niagara Falls, Clifton Hill? (Silence). What is there? What is there? The \\ Casino?] \\ S: $\quad$ Sí. [Yes]. \\ T: $\quad$ ¿Si? ¿El casino? ¿Fuiste al casino? ¿No fuiste? \\ [Yes? The Casino? Did you go to the Casino? You didn't go?]
}

As we see, there is an extensive amount of unpredictable question and answering, in which students are able to speak for as long as they wish, although usually students choose to answer in a minimal possible way.

Sustained speech: In this study there was only sustained speech from the part of students for oral reports. Nevertheless, this situation of lack of sustained speech is fairly normal in L2 classrooms, in which the learners' output usually consists of one or two sentences, as opposed to real native communication, where sustained speech is more common (Allen, 1983).

In general, the classes observed presented a large number of minimal utterances from both, students and teachers. In the case of students there was sustained speech in both sections at the private college, but only during oral presentations and, therefore, always in Spanish. In regards to the instructors at this college, there is very little sustained speech, in some cases in English and for this later situation of sustained speech in the L1, it was in reference to grammar explanations, especially during Participant \#2's second through fourth classes.

Some of Participant's 2 explanations were very extended and almost exclusively in English. This is the type of instance that could use "foreigner talk". Considering that this is a two-hundred level class, "foreigner talk", circumlocution and plenty of target language would have been appropriate.

In Participant's \#3 class, there were also few instances of sustained speech, mostly carried out by the instructor. Whenever Participant \#3 engaged in sustained speech, it took place in Spanish and it usually was in reference to administrative issues, such as comments regarding a test. During his last observed class there was an instance of very extended speech from the part of the instructor that lasted several minutes and reflects itself in the amount of speech carried out during this last class, as we see in table 2: 
Table 2: Participant \#3's fifth class

\begin{tabular}{|l|c|c|c|c|}
\hline \multicolumn{1}{|c|}{ Participant/s } & L1-English & L2-Spanish & Silence & Total \\
\hline Teacher speech & $1.9 \%$ & $60.4 \%$ & & $62.3 \%$ \\
\hline Student speech & $2.6 \%$ & $33.0 \%$ & & $35.6 \%$ \\
\hline Choral & $0 \%$ & $0 \%$ & & $0 \%$ \\
\hline Silence & & & $2.1 \%$ & $2.1 \%$ \\
\hline Total & $4.5 \%$ & $93.4 \%$ & $2.1 \%$ & $100 \%$ \\
\hline
\end{tabular}

As seen in Table 2 , teacher's speech was $62.3 \%$ of the total class time. There were also a few ultra minimal utterances expressed by students.

\section{Reaction to code or message}

We found that, except for Participants \#2 and \#3, daily initiation of class centered on communication, everything else after this initiation was grammar instruction. This focus on grammar took place in both languages, for both, students and instructors.

Focus on meaning was also observed, although in rare instances and mostly during oral reports, in which students tried to convey information without paying much attention to morphological issues and without being interrupted by the instructor.

In the case of Participant's \#1 classes focus on morphological issues, such as verb conjugations, was the only approach adopted. There were no communicative oriented activities, as there were in the other instructors' classes.

Incorporation of preceding utterances: The possibilities of incorporation of preceding utterances were: no incorporation, repetition, paraphrase, comment, expansion and elaboration.

In Participant's \#2 classes there was a large extent of a combination of repetition and comment together for most of the classes. An example of this combination, with predictable answers, which took place during the second class, follows:

T: ¿De qué es lo que vas a hablar?

[What are you going to talk about?]

S: $\quad$ Guatemala.

T: $\quad$ Guatemala, muy bien. ¿Dónde está Guatemala?

[Guantemala, very well. Where is Guatemala?]

S: $\quad$ Sur de México.

[South of Mexico]

T: $\quad$ Muy bien, al sur de México, muy bien. Así que primero vamos a ver lo que nos dice Jennifer [fictitious name] sobre... ¿Sobre qué es? (Pointing at another student).

[Very well, south of Mexico, very well. So, first we are going to see what Jennifer is going to say to us about ... what is it about?].

S: $\quad$ Guatemala.

T: $\quad$ Guatemala, muy bien.

[Guatemala, very well].

At the same time, we see the characteristic ultra minimal and minimal answers from the students to the information requests of the instructor. We also see the use of predictable request of information, which, as we saw under the "information gap" category, the teacher knows the answer in advance.

For Participant \#1, on the other hand, we could notice a predominance of no incorporation of preceding utterances, especially because of a constant change of topics during class.

For Participant \#3, the pattern was usually to repeat and comment, similar to Participant \#2. 
Discourse initiation: There were very few instances of discourse initiation from the part of the students in all fifteen classes observed. In the scarce times that discourse initiation took place it referred to a grammar question or a statement or comment regarding a grammatical issue. This was true for all sections. Participant's \#2 classes have the highest percentage of student discourse initiation, $7.08 \%$.

Relative restriction of linguistic form: These took the form of restricted use, limited use or unrestricted use. Transcripts show a mixture of all three subdivisions of linguistic forms, but especially limited and restricted ones in both instructors' students. An extract from Participant's \#2 second class illustrates this issue:

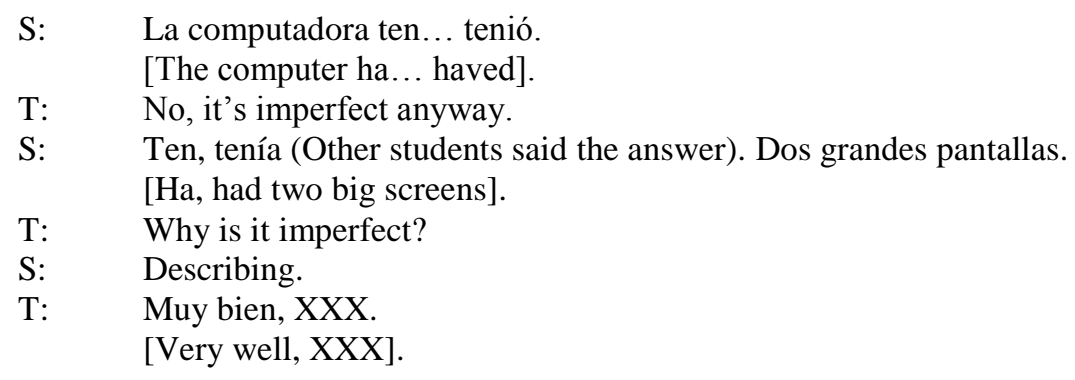

In this example, as in most of the classes observed, the restriction on the use of linguistic forms is due to the lack of flexibility that the exercises allow. When there was grammar instruction and students solved exercises there were seldom instances of unrestricted use of linguistic forms from the part of the teachers and none from the part of the students. On the other hand, student oral presentations allowed students to speak without an unrestricted use of forms.

In Participant's \#3 classes there was also a prevalence of restricted use of forms, since students were asked to write sentences in a specific verb tense. An example taken from his fouth class follows:

T: Demos un ejemplo en donde estamos utilizando "ser" para indicar una ocupación u oficio de una persona. A ver, un ejemplo.

[Let's give an example in which we are using "to be" to indicate occupation or trade of a person. Let's see, an example].

S: $\quad$ Mi madre es la profesora.

[My mother is the teacher].

T: $\quad$ Mi madre es profesora. No necesitas el artículo en realidad. Mi madre es profesora, muy bien, otro. another].

[My mother is (a) teacher. You don't need the article actually. My mother is (a) teacher, very well,

S: $\quad$ Mi amigo es mecánico.

[My friend is (a) mechanic].

T: $\quad$ Muy bien, mi amigo es mecánico, muy bien. Otro ejemplo.

S: $\quad$ Yo soy estudiante.

[Very well, my friend is (a) mechanic, very well. Another example].

[I am (a) student].

In this segment there is limited use "relative restriction of linguistic form". The verb "ser" has to be used in any tense, present, past or future, for which students chose to use the present tense of the verb "ser".

\section{CONCLUSION}

The Spanish classes observed in this study show the increasing focus on grammar and almost exclusive adherence to the text, that seem to be characteristic of foreign language classrooms at the college level in the United States. This focus on language form and not in communication creates a restriction on the amount and linguistic forms of language produced by the students. Given that the present study took place at conversation classes, the focus on grammar and not on communication deprives students from valuable time for actual communication. 
Student discourse also shows a prevalence of minimal and ultra minimal utterances with restriction of form. This restriction of form indicates that speech is mostly limited to the grammatical topic being covered the day that the lesson takes place. Another finding is the large amount of teacher speech, sometimes surpassing students' speech. This issue of high rates of teacher talk has been noted before, "Research reported from all over the world shows a similar pattern: in India, Belgium, Iraq, South America and New Zealand the teacher keeps on talking" (Holmes 1978, p. 80). Large amount of teacher talk usually results into teacher-centered classes, which deprive students from the possibility of producing valuable output, necessary in the students' interlanguage development.

Due to the findings in this research, it seems necessary that foreign language instructors be trained in alternatve approaches that allow more communication in the target language in the classroom. Communication that does not restrict the use of specific grammar or vocabulary and contains sustained and unpredictable information would be of great benefit to foreign language students for them to create in the language. It would also be of great benefit that future foreign language teachers are video-taped or tape recorded in order to rehearse activities and learn alternative approaches. Future foreign language instructors could also benefit from taking classes in a department of education to be acquainted with foreign language teaching methodologies.

From a pedagogical point of view, the researcher hopes to bring attention to the need of training future teachers and instructors on updated techniques that enable student center classrooms and provide the best results in foreign language teaching and learning process.

\section{AUTHOR INFORMATION}

Graziela Rondon-Pari is an assistant Professor of Spanish at the State University of New York, Colle at Brockport. Dr. Rondon-Pari obtained her Ph.D. in Foreign and Second Language Education from SUNY Buffalo. She also received a MS in Educational Psychology and an MA in Foreign Languages, specializing in Latin American Literature. Both Masters degrees were awarded by Southern Illinois University. She received a bachelors of Science in Spanish Secondary Education from Universiad Catolica in Peru. Her research interests include: Oral and Written proficiency assessments, foreign language methodology, error correction research. E-mail: grondonp@brockport.edu

\section{REFERENCES}

1. ACTFL (2002). Program Standards for the Preparation of Foreign Language Teachers. Yonkers, NY: The American Council on the Teaching of Foreign Languages.

2. Allen, P., Fröhlich, M., \& Spada, N. (1983). The communicative orientation of language teaching: An observation scheme. In J. Handscombe, R. A. Oream, \& B. P. Taylor (Eds.), On Tesol '83 (pp. 231-252). Bloomington, Illinois: Pantagraph Printing.

3. Allbright, D. \& Bailey, K. (1999). Focus in the Language Classroom. Cambridge University Press.

4. Canale, M. (1983). From communicative competence to language pedagogy. In J. Richards, and R. Schmidt, (Eds). Language and Communication (pp. 2-27). London: Longman.

5. Day, R. (1985). The use of the target language in context and second language proficiency. In S. Gass \& C. Madden (Eds.), Input in Second Language Acquisition (pp. 257-271). Rowley, MA: Newbury House.

6. Day, R. (1990). Teacher observation in second language teacher education. In J. Richards and D. Nunan, (Eds). Second Language Teacher Education (pp. 43-61). Cambridge, UK: Cambridge University Press.

7. De la Fuente, M. J. (2002). Negotiation and oral acquisition of L2 vocabulary: The roles of input and output in the receptive and productive acquisition of words. Studies in Second Language Acquisition, 24, 81-112.

8. Gass, S., \& A. Mackey (2006). Input, interaction and output: An overview. AILA Review, 19, 3-17.

9. Gass, S., \& Madden, C. (1985). Input in Second Language Acquisition. Rowley, MA: Newbury House.

10. Holmes, J. (1978). Sociolinguistic competence in the classroom. In J. Richards (Ed.) Understanding Second and Foreign Language Learning. Rowley, MA. Newbury House.

11. Krashen, S. (1985). The Input Hypothesis: Issues and Implications. London: Longman.

12. Lightbown, P., \& Spada, N. (2006). How Languages are Learned. Oxford University Press. 
13. Pearson, L., Fonseca-Greber, B., \& Foell, K. (2006). Advanced Proficiency for Foreign Language Teacher Candidates: What Can We Do to Help Them Achieve This Goal? Foreign Language Annals, 39(3), 507-

519.

14. Pica, T. (1996). Do second language learners need negotiation? International Review of Applied Linguistics, 34, 1-21.

15. Selinker, L. (1972). Interlanguage. International Review of Applied Linguistics, 10, 209-231.

16. Spada, N., \& Lyster, R. (1997). Approaches to observation in classroom research: Macroscopic and microscopic views of L2 classrooms. TESOL Quarterly, 31(4), 787-795.

17. Stavans, I. (2005). The challenge facing Spanish Departments. The Chronicle of Higher Education, 51(47), 6-8.

18. Swain, M. (1985). Communicative competence: Some roles of comprehensible input and comprehensible output in its development. In S. Gass \& C. Madden (Eds.), Input in Second Language Acquisition (pp. 235253). Rowley, MA: Newbury House.

19. Swain, M. (2000). The output hypothesis and beyond: Mediating acquisition through collaborative dialogue. In J. P. Lantolf (Ed.), Sociocultural theory and Second Language Learning (pp. 97-114). Oxford: UK. Oxford UP. 
NOTES 